\title{
The Northern Belt one hundred years on: A revised model of the Ordovician tracts near Leadhills, Scotland
}

\author{
R. A. Smith, E. R. Phillips, J. D. Floyd, H. F. Barron \& E. A. Pickett \\ British Geological Survey, Murchison House, Edinburgh EH9 3LA \\ (e_mail: r.a.smith@bgs.ac.uk)
}

Total number of words: 9453

Abstract: 225

Figures: 8

\begin{abstract}
A new model for the provenance, depositional environment and tectonic setting of the Northern Belt of the Southern Uplands is presented. This turbiditic sandstone dominated sequence was deposited in a sand-rich submarine fan environment, overlying hemipelagic mudstones. The oldest sandstones are rich in juvenile ophiolitic material and record the first clastic input into the Southern Uplands basin. The bulk of the Northern Belt sedimentary sequence, however, is dominated by relatively quartzose sandstones derived from a Proterozoic continental/metamorphic source represented by the Midland Valley terrane of Scotland and Ireland. The quartzose dominated sequence was punctuated by the input of fresh volcanic detritus shed from a oceanic/continental island-arc situated to the W/NW of the Southern Uplands basin, with sediment dispersal turning to the NE along the axis of the basin in Scotland. The tectonic setting of the Southern Upland basin remains uncertain. The complex provenance of the sandstones and recognition of major olistostrome units within the Northern Belt succession suggest that it was tectonically active. The onset of clastic deposition within the Southern Uplands broadly corresponds to ophiolite obduction in both Scotland and Ireland, possibly in response to collision of a Cambrian-early Ordovician island-arc system with the Laurentian continental margin. If this interpretation is correct then the possibility arises that the Southern Uplands-Midland Valley terranes record the dismembering of this island-arc complex within an overall transpressional regime.
\end{abstract}

Keywords: Southern Uplands, Ordovician, provenance, structure, sinistral strike-slip 


\section{Introduction}

Since the publication of Peach \& Horne’s (1899) memoir on the Silurian rocks of Britain (Volume 1. Scotland) there has been a significant increase in our understanding of the geology of the Northern Belt of the Southern Uplands (e.g. Armstrong et al., 1996, 1999; Owen et al., 1999; Danelian \& Clarkson 1998; Ogawa 1998; Floyd 1999). However, it was Nicol (1848), based upon his observation that the Northern Belt rocks are generally more rudaceous and immature than those in the Central and Southern belts, who first recognised that the main source of detritus for the Southern Uplands sedimentary sequence was from the $\mathrm{N}$. Work by Lapworth $(1870,1878)$ led to the development of much of the graptolite zonation which later proved the key to unravelling the stratigraphy and structure proposed by Peach \& Horne (1899). Peach \& Horne defined the Northern Belt as comprising Ordovician strata and considered that the presence of derived shelly faunas and thin graptolitic shales within the sequence indicated that it was deposited in a near shore, oceanic environment.

Subsequent work has led to the recognition that the Ordovician sandstone dominated sequence of the Northern Belt can be divided into a number of tracts by major NE-trending faults. The sequence is bounded to the $\mathrm{N}$ by the Southern Upland/Stinchar Valley Fault (SUF/SVF) and in the S by the Orlock Bridge Fault (OBF) (Fig. 1). Although details of the stratigraphy (see Floyd 1996 and references therein) and structure (e.g. Barnes et al., 1989; Ogawa 1998) are known there is still considerable debate concerning the evolution and tectonic setting of the Northern Belt sedimentary sequence. The structural configuration of the Southern Uplands, coupled with the association of early Caradoc to late Llandovery turbiditic wacke sandstones resting on the thin pelagic sequence of the Moffat Shale Group (MSG) provide the principal lines of evidence for the Northern Belt forming part of a fore-arc accretionary prism (McKerrow et al., 1977; Leggett et al., 1979). Alternative models, however, consider the Northern Belt sedimentary sequence to have been deposited in a back-arc basin (Hutton \& Murphy 1986; Morris 1987; Stone et al., 1987), or more recently in an extensional basin formed adjacent to a continental margin (Armstrong et al., 1996).

Recently the BGS and its co-workers have employed a multidisciplinary approach to the study of the Northern Belt; involving systematic field mapping, stream sediment (Stone et al., 1991) and whole-rock geochemical (Duller \& Floyd 1995; Phillips et al., 1995; Phillips et al., 1999) analysis as well as regional metamorphic (see Merriman \& Roberts this volume), structural and geophysical (Floyd \& Trench 1989) studies in order to understand its evolution and relationship to the surrounding terranes. The primary objectives of this paper are to provide a brief review of previous work as well as the stratigraphy, structure and possible tectonic setting of the Northern Belt (see Floyd this volume), and present a model for the evolution for the northern part of the Southern Uplands based upon new work in the New Cumnock and Leadhills districts (Fig. 1). 


\section{Stratigraphy, provenance and depositional environment of the Northern Belt sedimentary sequence}

The Arenig to Ashgill sedimentary sequence of the Northern Belt is dominated by turbiditic wacke sandstones of the Tappins, Barrhill and Scaur groups (Floyd 1996 and references therein) which overlie a condensed sequence of black graptolitic mudstones (Moffat Shale Group) and cherts (Crawford Group). The chert and mudstone sequences are locally associated with small volumes of basaltic volcanic rocks (Lambert et al., 1981; Phillips et al., 1995).

\subsection{Crawford Group}

The Crawford Group (inset Fig. 1) comprises a thin sequence of red and grey cherts and cherty mudstones which locally overlie, or are interbedded with basaltic volcanic rocks. The oldest cherts, referred to as the Raven Gill Formation, occur within the Leadhills Imbricate Zone (LIZ) (Fig. 1). These locally mottled cherts commonly contain radiolaria which are altered or poorly preserved due to early diagenesis. In modern analogues radiolarian cherts are deposited in an oceanic environment in areas of upwelling cool water associated with high planktonic productivity. Alternatively, the cherts may be related to contemporaneous volcanism. No volcanic material has been found within the cherts, however, it is possible that volcanic activity provided the source of the silica for the radiolaria. The volcanic rocks include altered and deformed, variably amygdaloidal basic lavas, dolerites and volcaniclastic rocks. The lack of vesicles/amygdales within the tholeiitic basalts exposed in the area to the NE of Hawkwood Burn has been used to suggest that they were erupted into deep water ( $>2 \mathrm{~km}$ ) (Fitton \& James in Clarkson et al., 1993).

Conodonts present within the associated cherty mudstones define two distinct faunal assemblages; the first ranging from mid-Arenig to latest Llanvirn, and second within the earliest Caradoc (Armstrong et al., 1996). The time gap between these two faunal assemblages led Armstrong et al. (1996) to suggest that they represent two distinct oceanographic settings. However, the stratigraphy and structure of the Crawford Group within LIZ does not support this conclusion. The cherts have recently been examined for radiolaria by Danelian \& Clarkson (1998) who tentatively correlated the radiolarian faunas with those of Llanvirn (Llandeilian)-Caradoc age. The sponge species Konyrium varium, identified within these cherts for the first time (Danelian et al., 1999), is at present only known from the Llanvirn or very latest Arenig of America and Kazakstan. The basaltic lavas within the LIZ volcanic rocks have yielded an Sm-Nd isotopic age of $490 \pm 14$ Ma (Thirlwall in McKerrow et al., 1985) providing an early Arenig age for volcanism within the Crawford Group. Consequently, the Crawford Group is believed to represent a continuous, albeit condensed, succession from the Arenig into the Caradoc. The Crawford Group, therefore, spans a time interval of $>20$ Ma during which there was only limited basic volcanism, but more importantly a complete lack of any major influx of terriginous clastic detritus into the Southern Uplands sedimentary basin. 
The tectonic setting of the Southern Uplands sedimentary basin during the deposition of the Crawford Group remains uncertain. The oceanic affinity of the radiolarian deposits was taken as an indication that they were deposited well within the Iapetus Ocean (Leggett 1987). However, these rocks are now known to possess rare earth element (REE) characteristics typical of cherts deposited in a continental margin setting (Armstrong et al., 1999). The basalts present within the LIZ include alkaline within-plate basalts and tholeiitic basalts which display geochemical characteristics of mid-ocean ridge basalts (Fig. 3) (Phillips et al., 1995). Lambert et al., (1981), in support of the fore-arc accretionary prism model, interpreted the geochemistry of these basic igneous rocks in terms of an early rifting event followed by ocean floor spreading. However, there is no unequivocal evidence to suggest that these events occurred within a major ocean basin (i.e. the Iapetus Ocean). Consequently, the overall setting of the Southern Uplands basin during deposition of the Crawford Group may have been in either an open ocean (Leggett 1987), back-arc basin (Stone et al., 1987) or continental marginal rift basin (Armstrong et al., 1996).

\subsection{Moffat Shale Group}

The Moffat Shale Group of the Northern Belt comprises a sequence of mainly black, graptolitic (gracilis-linearis) mudstones and silty mudstones which occur as thin, tectonically bound slivers on the NW side of the main tract-bounding faults (Fig. 2). The group becomes progressively younger in the tracts towards the $\mathrm{S}$ indicating a limited diachroneity (Caradoc-Ashgill) to the base of the overlying turbiditic sandstone dominated sequence (inset Fig. 1). In the northern most tract, below the Marchburn Formation, the MSG is absent. At the base of the northern, older part of the Kirkcolm Formation the MSG is relatively thin and passes upward through grey interlaminated siltstones into the overlying wacke sandstones. This MSG unit is exposed in Back Burn [NS 790 159] where it is bound to the SE by the Howcon Fault (Fig. 2) and contains thin, pale coloured bentonitic mudstone horizons which are interpreted as ashfall tuffs. Further to the S within the LIZ, the Moffat Shale and Crawford groups are imbricated (see Fig. 2) with the black silty mudstones of the MSG passing upward into sandstones belonging to the southern (younger) part of the Kirkcolm Formation. Rushton \& Stone (1991) suggested that the MSG represents background sedimentation within an oceanic Southern Uplands sedimentary basin.

The bentonites present within the MSG are calc-alkaline in character and have been used to suggest that the group was deposited in a back-arc basin bordering an ensialic volcanic-arc terrane (Merriman \& Roberts 1990). Small volumes of basaltic volcanic rocks, which occur with the MSG of the Gabsnout Burn north of Glenluce [NX 204 613], display geochemical characteristics of transitional to volcanic island-arc basalts (Fig. 3) (Phillips et al., 1995). However, these lenticular bodies of dolerite and basalt are thought to be allochthonous and may be older than the surrounding shales, possibly representing 
large rafts or olistoliths shed from a local elevated area of basic igneous material during the late Caradoc (Phillips et al., 1995; Barnes et al., 1996).

\subsection{Tappins Group}

The Tappins Group is the oldest sandstone dominated unit within the Southern Uplands. It is distinguished from the remainder of the Northern Belt sedimentary sequence by its overall higher magnetic susceptibility (Floyd \& Trench 1989) and high Cr and Ni content of the sandstones (Duller \& Floyd 1995; Stone et al., 1991). The base of the group is faulted and lacks any underlying MSG. In the SW part of the Northern Belt, between the Stinchar Valley and Glen App faults, it is represented by the Corsewall Formation (Fig. 1). Intercalated mudstones within the formation have yielded graptolites belonging to the $N$. gracilis Biozone and possibly the overlying Climacograptus peltifer Biozone (early Caradoc) (Cameron et al., 1986). NW-derived conglomeratic units (Figs. 4 and 5) within the Corsewall Formation contain a range of igneous (granite, rhyolite, andesite, gabbro, diorite) and metamorphic (amphibolite, quartzite, mylonite) rock fragments (Phillips \& Floyd 1999) forming pebble to boulder sized clasts. Granitic clasts from the Corsewall conglomerates have yielded Rb-Sr whole-rock ages in the ranges 470-490 Ma, 600-700 Ma and c. 1200 Ma (Elders 1987). However, the Grenvillian ages from the clasts of deformed two-mica granite are very poorly constrained (cf. Armstrong et al., 1996).

To the NE, between the SUF (sensu stricto) and the Carcow Fault (Figs. 1 and 2), the Tappins Group is represented by the Marchburn Formation (Floyd 1996). This sandstone dominated formation (Fig. 4) also contains cherty mudstones, siltstones as well as debris flow/slump deposits at or near its base and a distinctive microconglomerate, referred to locally as Haggis Rock (Fig. 4). In general, there is little evidence of intercalated black graptolitic mudstone within the Marchburn Formation. However, red cherty mudstones exposed near Leadburn [NS grid reference], have yielded conodonts associated with graptolites belonging to $P$. anserinus and $N$. gracilis biozones (Caradoc), respectively. Peach \& Horne (1899) collected fragments of $N$. gracilis (?lower part of the gracilis Biozone, Rushton 1995) from siliceous black mudstones exposed to the NW of Sanquhar [NS 744 173], which occur stratigraphically below the red cherty mudstones.

The Haggis Rock microconglomerate is interpreted as a mass or debris flow deposit and forms thick ( $\leq$ $50 \mathrm{~m}$ thick) graded, channel-like units ( $\leq 1 \mathrm{~km}$ wide) with sharp erosive bases. It is characterised by the presence of red, grey-green and black chert and mudstone fragments, but also contains granule to small pebble sized clasts of basalt, quartz, intermediate to acidic igneous rocks and high-grade metasedimentary rocks (indicative of a mixed continental/volcanic source). The proportion of Haggis Rock within the sequence decreases in the Peebles area (Fig. 4), probably reflecting facies changes within the Marchburn Formation which, in general, fines towards the NE (see Fig. 5). 
The thickly bedded, turbiditic wacke sandstones are quartz-poor, but rich in detrital clinopyroxene (Styles et al., 1995), magnetite, metabasalt, gabbro and serpentinite. Petrological (see Floyd 1996), geochemical (Duller \& Floyd 1995) and isotopic (Evans et al., 1991; Stone \& Evans 1995) studies indicate that juvenile ophiolitic detritus was being introduced into both the Corsewall and Marchburn formations. Sedimentological evidence (Walker 1978) indicates that the Marchburn Formation was deposited in a proximal, sand-rich submarine fan environment, with the microconglomerates representing channel-fills and the finer muds and silts, overbank deposits. In the New Cumnock and Leadhills areas (Fig. 4) the Marchburn Formation records an overall fining-upwards succession suggesting either a switching of the feeder channels resulting in fan-lobe abandonment, or that the basin was starved of coarse clastic detritus. Sparse palaeocurrent evidence is mainly from the NE or NW (Figs. 4 and 5) and probably records both axial and transverse transport directions within the NE-SWtrending Southern Uplands basin.

The Marchburn Formation sandstones are locally interbedded with basaltic pillow lavas, associated with volcanic breccias and red to grey-green cherts (e.g. the c.100 m thick Noblehouse Lava Member of the Leadburn area). These alkaline and tholeiitic basalts are entirely of within-plate oceanic affinity (Fig. 3) (Phillips et al., 1995). Also within the Tappins Group, but separated from the main part of the group by a series of minor faults, are the Downan Point Lava, Dalreoch and Currarie formations (early Caradoc, Armstrong et al., 1998). The Dalreoch and Currarie formations comprise turbiditic sandstones overlying a sequence of mudstone, chert and basaltic lava. The Downan Point lavas are tholeiitic, with basalts analysed from the Currarie Formation being alkaline in composition. Both suites show geochemical characteristics and trace element enrichment patterns typical of oceanic within-plate basalts (Fig. 3).

\subsection{Barrhill Group}

The Barrhill Group occurs between the Glen App/Carcow and Leadhills faults (Figs. 1 and 2), and includes the Kirkcolm, Galdenoch and Blackcraig formations (Fig. 6). The Kirkcolm Formation is mainly composed of massive, sheet fan turbiditic sandstones with intervals of interlaminated siltstone and mudstone. It is at least $3 \mathrm{~km}$ thick and dominates much of the Northern Belt. The sandstones are rich in acidic volcanic detritus and possess geochemical characteristics comparable to sandstones deposited in an active continental margin setting (Duller \& Floyd 1995). In detail, in SW Scotland and Peebles area the formation is cut by several strike-parallel faults and is divided into two main subtracts by the Glaik Fault (Fig. 1). To the north of the fault the Kirkcolm Formation contains both gracilis and peltifer biozones, whereas to the $\mathrm{S}$ of this structure clingani Biozone faunas occur within the MSG below the Kirkcolm Formation (Floyd 1996). The Eller Fault in the Sanquhar-Leadhills area (Fig. 2) may be equivalent to the Glaik Fault. To the WNW of Leadhills (Fig. 2), the southern, younger part of the Kirkcolm Formation includes a NW-derived conglomeratic unit, the Duntercleuch Conglomerate (see Fig. 5). This coarse, pebbly, poorly sorted conglomeratic unit contains a suite of acid igneous 
(granite, granophyre, tonalite, quartz- and quartz-feldspar phyric rhyolite) and medium-grade metasedimentary (mica schist, semipelite, quartzite, psammite, mylonite) rock fragments. Derived fossils, including Kilbuchophyllia sp., crinoid and trilobite fragments (upper peltifer to lower clingani Biozone), present within the conglomeratic beds have been used to support the presence of a former shelf area to the NW (Owen \& Clarkson 1992; Clarkson et al., 1992).

The base of the Blackcraig Formation is conformable upon the Kirkcolm Formation and, despite its top being cut by the Langlee Fault (Fig. 2), in cross section it appears to form a large channelised unit composed of thick to massive bedded conglomerates and coarse-grained sandstones. These sandstones are distinguished by their high modal proportions of detrital epidote, amphibole and clinopyroxene; the latter being derived from a complex, mixed calc-alkaline and alkaline non-orogenic (ocean ridge, backarc basin, continental rift, ocean island) provenance (Styles et al., 1995). Whole-rock geochemical studies (Duller \& Floyd 1995) indicate that these sandstones are compositionally similar to rocks deposited in an oceanic/continental island-arc setting. NW-derived conglomeratic beds present within the Blackcraig Formation (Fig. 5) contain pebbles to boulder sized clasts of igneous, metamorphic and sedimentary rock fragments which comprise a similar range of lithologies to those found within the Corsewall Formation conglomerates (Phillips \& Floyd 1999).

The Galdenoch Formation (Fig. 4), which is approximately the same age as the Blackcraig Formation, also comprises a sequence of medium-grained, ferromagnesian-rich (clinopyroxene, hornblende) sandstone. The Galdenoch Formation sandstones form shallow, broad channels or sheets within the Kirkcolm Formation. The size and number of these channels decreases towards the NE. Detrital clinopyroxene within the Galdenoch Formation sandstones are interpreted as having been derived from a transitional tholeiitic to calc-alkaline volcanic arc source (Styles et al., 1995) (see Fig. 5). The sandstones and rare conglomeratic units also contain abundant wacke sandstone, siltstone, and occasional chert fragments (Owen et al., 1999) recording penecontemporaneous erosion within the Southern Uplands basin. Hutchison \& Oliver (1998) have recently suggested that detrital garnets present in the Kirkcolm and Galdenoch formation sandstones were derived from the Dalradian of the Scottish Highlands; an interpretation they believe is supported by the similarity between mica cooling ages from the Dalradian (Dempster 1985) to those of detrital micas in the Northern Belt (Kelley \& Bluck 1989). However, almandine-rich garnet is common within many Barrovian regionally metamorphosed terranes and, therefore, does not provide unequivocal evidence for the Grampian terrane being the source of metamorphic detritus to the Southern Uplands.

In the New Cumnock-Leadhills area the Kirkcolm Formation locally (e.g. Poltallan Burn [NS 696 069]) contains relatively thin (1 to $10 \mathrm{~m}$ thick) volcanic breccia beds intercalated with siltstone and silty mudstone (Poltallan Member) (Fig. 2). Two facies of volcanic breccia are exposed; the first is a pyroclastic deposit with lenses of lava in a streaky tuffaceous matrix, and the second is a rubbly epiclastic type. These highly altered, volcanic breccias contain clasts ( 0.1 to $20 \mathrm{~cm}$ in size) of fine- 
grained basalt, amygdaloidal basaltic lava and sandstone in a poorly sorted clastic matrix. Initial geochemical analysis of a lava clast indicates that it is possibly alkaline within-plate in character (Fig. 3). Intercalated with the sandstones at the base of the northern part of the Kirkcolm Formation is a sequence of alkaline basaltic to trachyandesitic lavas, volcaniclastic and intrusive rocks which form the Bail Hill Volcanic Group (Phillips et al., 1999). These volcanic rocks possess geochemical characteristics and trace element enrichment patterns typical of oceanic within-plate basalts (Fig. 3). Penecontemporaneous erosion of the Bail Hill volcanic edifice provided a localised source of detritus to the Stoodfold Member of the Kirkcolm Formation (Fig. 2). This member can be traced for approximately $15 \mathrm{~km}$ along strike to the NE of the main area of outcrop of the Bail Hill Volcanic Group. The distribution of this member provides evidence of a more complex sediment dispersal pattern within the Southern Uplands basin involving $\mathrm{N}$ or NE-directed transport counter to the predominantly SW axial palaeoflow. The Bail Hill Volcanic Group is overlain by a major sedimentary breccia/slump deposit (Fig. 2) which is up to $700 \mathrm{~m}$ thick and contains rafts/olistoliths (up to $150 \mathrm{~m}$ in length) of wacke sandstone, graptolitic mudstone (upper gracilis Biozone, Rushton 1995), siltstone and chert. This olistostrome is the largest slump deposit recorded so far in the Northern Belt and it may have covered the Bail Hill volcanic edifice as it impacted the SE-propagating thrust stack. Smaller slump deposits occur elsewhere within the Kirkcolm and Marchburn formations so, alternatively, these deposits can be interpreted as recording seismic activity within the Southern Uplands basin, possibly associated with extension accompanying the within-plate volcanism.

\subsection{Scaur Group}

The Scaur Group is dominated by the Portpatrick Formation which comprises a sequence of turbiditic wacke sandstones that are rich in andesitic detritus derived from a calc-alkaline, continental island-arc source (Styles et al., 1989; Duller \& Floyd 1995). Kelling et al. (1987) suggested that the formation is slightly diachronous, becoming younger toward the NE were it has a more mixed calc-alkaline to transitional volcanic-arc provenance (Styles et al., 1995). Palaeocurrent indicators suggest that the Portpatrick Formation sandstones were mainly derived from the SW (Fig. 5), but locally also from the SE (Evans et al., 1991). This sedimentological evidence has been used in support of a back-arc basin setting for the Northern Belt and existence of a southerly andesitic volcanic-arc founded on continental crust (Stone et al., 1987; Styles et al., 1989; Evans et al., 1991). However, in Ireland the equivalent to the Portpatrick Formation appears to have been derived from the NW (Craig 1984). One explanation may be that the main source of volcanic detritus to the Portpatrick Formation lay to the W/NW with initial transverse palaeoflow in Ireland turning to the NE along the axis of the basin in Scotland.

Intercalated within the Portpatrick Formation are the relatively quartzofeldspathic turbiditic sandstones of the Glenwhargen Formation. The formation thins towards the NE, from over $500 \mathrm{~m}$ in the SW of the Southern Uplands (Floyd 1999) down to approximately 100-200 m thick in the New Cumnock area 
(Fig. 2), suggesting that the main source of quartzofeldspathic detritus to the Glenwhargen Formation lay to the SW (Fig. 5).

\subsection{Shinnel Formation}

The Shinnel Formation (Fig. 1) is petrographically similar to the Kirkcolm Formation, and comprises a sequence of relatively quartzose, turbiditic sandstones with several, minor conglomerate filled channels (Fig. 2). The sandstones possess geochemical characteristics comparable to rocks deposited in an active continental margin setting (Duller \& Floyd 1995). Interbedded mudstones within the Shinnel Formation of the New Galloway area contain anceps Biozone faunas (Floyd \& Rushton 1993). Isotopic studies suggest that the sandstones were largely derived from a Proterozoic continental source (Evans et al., 1991). In the Peebles area (Fig. 1), the formation contains olistoliths of peralkaline rhyolite (Tweeddale lavas) and fossiliferous limestone (Wrae Limestone) (Fig. 6). Thirlwall (1981) demonstrated that the rhyolites were originally erupted in a within-plate oceanic setting (see Fig. 3). The associated limestone clasts contain a P. anserinus Biozone fauna and probably represent reworked U. Llanvirn- L. Caradoc strata.

\subsection{Glenlee Formation}

The Glenlee Formation crops out between the Glen Fumart and Orlock Bridge faults, and is the youngest formation within the Northern Belt (Fig. 1). It mainly consists of a sequence of turbiditic sandstones, but also locally contains a thick (at least 1000 m thick) laminated siltstone member. This siltstone member contains thin black shales which have yielded graptolites from the Upper (pacificus) Subzone of the anceps Biozone, as well as possible, younger persculptus Biozone faunas (Floyd 1996). The siltstone member may be equivalent to the laminated siltstones exposed at Dob’s Linn which were deposited during Ashgillian glaciation (Armstrong \& Coe 1997). It is possible that turbiditic sequence spans more than one graptolite zone because black mudstone was not deposited during the glaciation.

Some of the sandstone turbidites are rich in andesitic and dacitic rock fragments. Detrital clinopyroxenes, which form a minor component of some sandstones, appear to have been derived from a calc-alkaline to tholeiitic volcanic arc to transitional source (Styles et al., 1995).

\section{Structure and metamorphism of the Northern Belt}

The Southern Uplands comprises a series of elongate NE-SW-trending fault bounded tracts which contain steeply dipping to vertical, sandstones and mudstones which commonly overlie pelagic black shales of the MSG. Internally each tract youngs toward the NW (Fig. 7). Biostratigraphical evidence indicates that these tracts become progressively younger to the SE with the overall structure of the terrane being interpreted as a SE-verging imbricate thrust stack (McKerrow et al., 1977; Leggett et al., 
1979; Stone et al., 1987). One feature of the Southern Uplands thrust stack which has not been explained in any of the published structural models is how the coherent nature of these elongate, narrow tracts was maintained during deformation. This diachronous deformation sequence has, however, been well documented by Barnes et al. (1989) (also see Anderson this volume). The first phase (D1) folding and cleavage development becomes progressively younger to the $\mathrm{S}$ as the thrust stack propagated to the SE. In the Northern Belt tracts early (F1) folds are consistently gently to moderately plunging (Barnes et al., 1989) and are associated with a predominantly axial planar cleavage (Anderson 1987). A change in the regional stress regime in the late Llandovery to early Wenlock is recorded by an increasingly significant component of sinistral shear. Available biostratigraphical, tectonostratigraphical and isotopic age data (e.g. Rock et al., 1986) constrain the age of the peak of this sinistral shear event (D3) to the mid-Wenlock (c. 425 Ma). In the previously deformed Northern Belt, D3 resulted in localised folding and shearing associated with sinistral wrench movements on, and adjacent to, the now steeply dipping thrust faults.

The overall parallel pattern of the tracts in the Northern Belt combined with the axial planar nature of S1 with respect to the F1 folds argues for essentially orthogonal accretion/thrusting during at least the early stages of the deformation history. The tract bounding faults initially developed as low-angle D1 thrusts with the plane of detachment typically occurring within the MSG, commonly just above the cherts and/or basalts of the underlying Crawford Group. However, in the New Cumnock-Leadhills area the base of the Marchburn Formation is cut by the Carcow Fault (Fig. 1) and lacks any obvious MSG. Consequently, the initial control on the location of this fault is uncertain. It may be suggested that detachment occurred at the contact between the Marchburn Formation and the underlying basement, possibly formed by oceanic crust. The latter may be represented, at least in part, by the Downan Point lavas. However, no lenses of basaltic material have been recognised along the Carcow Fault. In the Leadhills area the Carcow Fault is locally structurally overlain by a sedimentary breccia/olistostrome (Fig 2) which may have been generated in response to syn-sedimentary faulting. It is possible that slumping and localised disruption of the Northern Belt sedimentary sequence records the onset of D1 thrusting which, in this case, would have been penecontemporaneous with the deposition of the Marchburn Formation. Alternatively, these deposits may be recording seismic activity within the Southern Uplands basin associated with extension accompanying within-plate volcanism.

The Marchburn Formation tract, which is bounded by the Southern Upland and Carcow faults, narrows towards the NE. This thickly bedded sandstone-microconglomerate dominated tract is internally relatively undeformed. In the Peebles area, strike-parallel faults occur within the tract leading to the repetition/imbrication of the Noblehouse Lava Member. Large-scale F1 folds deforming a cherty mudstone have been recognised near Kirkland Hill [NS 731 162], N of Sanquhar. However, in its type area the Marchburn Formation forms a through succession younging towards the NW. Close to the SVF, the Tappins Group has been affected by later (D3) sinistral shearing along this terrane boundary (Floyd 1994). 
As previously stated the Kirkcolm Formation in the New Cumnock-Leadhills area can be divided into at least two 'subtracts' by the Eller Fault (Figs. 2 and 7). In this area the older, northern, Kirkcolm Formation 'subtract' is internally deformed by the Howcon and Coarsegravel faults (Fig. 2). These faults repeat parts of the Kirkcolm Formation sedimentary sequence and, therefore, provide evidence of localised thrust repetition within the main Northern Belt tracts. W of Sanquhar (Fig. 2), F1 fold pairs have been rotated into an E-W trend (Smith 1999), with clockwise rotation probably occurring in response to subsequent D3 sinistral shear along the tract bounding faults. Thrust repetition also occurs within, and immediately adjacent to the LIZ and Fardingmullach Fault (Fig. 2); the latter forming the southern boundary to the Portpatrick Formation. Imbrication probably occurred in response to the development of small scale thrusts rising from the main decollement which, in the case of the LIZ, is located within the MSG above the underlying basic igneous rocks. Within the Portpatrick Formation these faults are marked by slivers of Moffat Shale (Fig. 2).

The pattern and grade of regional metamorphism within the Northern Belt is consistent the younger strata having buried beneath the older strata within an accretionary prism (Merriman \& Roberts this volume), with the lowest metamorphic grades occurring within the Marchburn Formation. In the New Cumnock-Leadhills area the metamorphic grade, based upon illite crystallinity values from the metapelitic rocks, ranges from diagenetic to low-anchizone (Merriman \& Kemp 1998). The strike parallel tract-bounding faults tend to control the pattern of metamorphic grade, indicative of a close relationship between thrusting and the regional metamorphism. The grade of metamorphism tends to be slightly higher adjacent to these faults, for example the Fardingmullach Fault, reflecting an increase in strain adjacent to these major structures. The grade then appears to fall off towards the stratigraphic top of the tract; as might be expected during burial metamorphism.

\section{Discussion: a revised model for the Northern Belt}

Geotectonic models have linked deformation within the Southern Uplands to the closure of the Iapetus Ocean requiring the Ordovician Northern Belt sedimentary sequence to have been deposited in: a trench associated with NW-directed subduction (McKerrow et al., 1977; Leggett et al., 1979); a back-arc basin (Hutton \& Murphy 1986; Morris 1987; Stone et al., 1987); or more recently an extensional basin formed adjacent to a continental margin (Armstrong et al., 1996). The back-arc basin model is reliant upon the presence of a southern calc-alkaline volcanic source to explain the interdigitation of the arcrelated detritus with quartzose continental derived sandstones. However, the diachronous southerly pattern of younging within the Southern Uplands sedimentary pile argues against the prolonged presence of such a source area. Furthermore, palaeoflow in the Southern Uplands basin appears to have been mainly axial (see Fig. 5), comparable to sediment transport within a trench system. Oceanward derived palaeocurrents do occur within the forearc setting, for example the Shimanto Belt of Japan (Taira et al., 1982). Consequently, the tectonic setting of the Ordovician sedimentary sequence within the Northern Belt of the Southern Uplands needs to be critically re-examined. 
A broadly subduction related setting for the Southern Uplands basin has largely been based upon the presence of wacke sandstones within the Blackcraig, Galdenoch, Portpatrick and Glenlee formations which contain a high proportion of fresh volcanic detritus. Mineral (Styles et al., 1995) and whole-rock geochemical (Duller \& Floyd 1995) studies indicate that these sediments were derived from an oceanic to continental island-arc source. However, isotopic ages (540-560 Ma, ${ }^{40} \mathrm{Ar}-{ }^{39} \mathrm{Ar}$ whole-rock) published by Kelley \& Bluck $(1989,1990)$ suggest that andesitic volcanic detritus present within the Portpatrick Formation may have been derived much older mid-Cambrian to Arenig island-arc. Consequently, the existence of fresh volcanic material within the Southern Uplands sedimentary sequence may simply reflect a limited period of transport within the sedimentary environment, coupled with rapid burial and removal from the system. The only apparently arc-related Ordovician volcanic rocks within the Southern Uplands are allochthonous within the MSG and interpreted as having been derived from a local elevated area of older basic igneous material (Phillips et al., 1995; Barnes et al., 1996).

It is rarely emphasised that the Southern Uplands sedimentary sequence is, in fact, dominated by relatively quartzose sandstones (e.g. the Kirkcolm and Shinnel formations) which appear to have been largely derived from a Proterozoic continental source (Evans et al., 1991). Cooling ages (Kelley \& Bluck 1989, 1990) determined for detrital micas and metamorphic rock fragments from the Kirkcolm and Shinnel formation sandstones provide an age of uplift and erosion of this continental source of 450 to 480 Ma. Comparable ages (450-480 Ma; 550-650 Ma, Rb-Sr whole-rock) have been determined for granitic clasts from conglomeratic units within the Corsewall and Blackcraig formations (Elders 1987) and NW-derived Ordovician conglomerates in the Girvan area (Longman et al., 1979) of the Midland Valley. The source for the Girvan conglomerates is believed to have been within the Midland Valley terrane and included the Ballantrae ophiolite complex (Bluck 1983). The latter may have also provided the source for the juvenile material being supplied to the Southern Uplands during the deposition of the Marchburn Formation.

Further evidence for the Midland Valley terrane having supplied material into the Southern Uplands includes the presence of derived fossils (e.g. Kilbuchophyllid corals) within the Duntercleuch Conglomerate which have many similarities to the fauna present within the Caradocian mudstones and limestones of the Bardahessiagh Formation, Pomeroy, Co. Tyrone (Scrutton et al., 1998). The Bardahessiagh Formation also includes a shallow marine clastic sedimentary sequence of calcareous sandstone, siltstone, mudstone and quartz-pebble conglomerate. The slightly older Caledonian and Proterozoic (Daly 1996) basement to these rocks, the Tyrone Igneous Complex, comprises: (1) Highgrade (garnet \pm sillimanite) metasedimentary rocks; (2) An ophiolitic complex of gabbro, dolerite and pillow basalts obducted during the Arenig to Llanvirn (c. 472 Ma, Hutton et al., 1985); and (c) an Arenig-Llanvirn volcanic suite, ranging from pillow basalt, through basaltic (hornblende) andesite and dacite, to rhyolite, which is associated with chert, siliceous ironstone and black shale. These volcanic rocks are intruded by calc-alkaline granites, granodiorites, diorite, granophyres, tonalites and quartz- 
feldspar porphyries. A remarkably similar range of igneous and metamorphic rocks to those present within the Tyrone Igneous Complex occurs as clasts within the Corsewall, Blackcraig and Duntercleuch conglomerates of the Southern Uplands.

An attempt has been made to model the relative positions of the Southern Uplands and Midland Valley terranes during the Caradoc (Fig. 8) based upon an estimate of approximately 200-250 km of sinistral displacement (Clarkson et al., 1992; Scrutton et al., 1998) along the SUF and related structures. Figure 8 shows the relative juxtaposition of the Southern Uplands, Midland Valley and Connemara (Dalradian) terranes and the potential sources of volcanic-arc, ophiolitic, plutonic igneous and metasedimentary detritus to the NE-SW-trending Southern Uplands sedimentary basin. The main potential source of ophiolitic material to the Marchburn Formation was probably the Ballantrae ophiolitic complex which was obducted onto the Midland Valley terrane during the Arenig (see Cameron et al., 1986). The extension of the Midland Valley terrane in Ireland is represented by the Tyrone Igneous Complex and the unconformably overlying Lower Palaeozoic rocks. The NW part of the Midland Valley terrane in Ireland has been overthrust by the Grampian terrane, so the source area for Midland Valley detritus may have been much larger. This area was probably located to the NW of the Southern Uplands basin (Fig. 8) and, therefore, may have provided arc-related volcanic, granitic plutonic, sedimentary and metasedimentary material to the Corsewall, Kirkcolm and Blackcraig formations. An alternative source of older island-arc volcanic rocks for the Portpatrick Formation may be found within the TremadocLlanvirn rocks of the Curlew Mountains and/or South Mayo Trough (Hutton 1987 and references therein). This interpretation is compatible with the SW palaeoflow direction recorded by the andesiterich Portpatrick Formation turbiditic sandstone (Fig. 5). The location of the W/SW source of quartzose continental/metamorphic detritus for the Shinnel Formation (see Fig. 5) remains uncertain. It is tempting to suggest that this source is represented by the Dalradian terrane of Connemara (Fig. 8) which had docked against the South Mayo Trough by Upper Llanvirn (Llandeilian) times (Hutton \& Dewey 1986). However, Sm/Nd isotopic provenance studies (Evans et al., 1991) have not found any evidence for a Dalradian source having contributed detritus to the Northern Belt.

The tectonic setting of the Southern Upland basin remains uncertain as both the forearc/trench and back-arc basin models do not fully explain the geology of this complex terrane. The complex provenance of the sandstone dominated sequence and recognition of major sedimentary breccia/olistostrome units within the Northern Belt suggest that it was tectonically active. This contrasts markedly with preceding c. 20 Ma period recorded by the Crawford Group in which there was only limited basic volcanism and a complete lack of terriginous clastic input into the Southern Uplands basin. The predominantly quartzose nature of the Northern Belt sandstone dominated sequence suggest that this basin was located adjacent to the Laurentian continental margin which is, at least in part, represented by the Midland Valley terrane of Scotland and Ireland. The dominance of within-plate basaltic volcanism within the Southern Uplands basin indicate that it was undergoing extension during the Caradoc and that it was founded upon oceanic crust (Phillips et al., 1995; Phillips et al., 1999). The 
onset of clastic deposition and ?deformation within the Southern Uplands broadly corresponds to ophiolite obduction in both Scotland (Ballantrae) and Ireland (Co. Tyrone). This phase of obduction may have been generated by the collision of a Cambrian-early Ordovician island-arc system (South Mayo Trough, Curlew Mountains, Co. Tyrone) with the Laurentian continental margin. If this interpretation is correct then the possibility arises that the Southern Uplands-Midland Valley terranes record the dismembering of this island-arc complex with volcanic detritus eroded from this arc being intermittently supplied to the Southern Uplands sedimentary basin. Although the initial phases of deformation within the Southern Uplands are apparently orthogonal, the overall tectonic regime may have been one of sinistral strike-slip. A sinistral strike-slip model has recently been suggested to explain the Ordovician-Silurian evolution of the Midland Valley terrane in Scotland (Smith 1995; Phillips et al., 1998). Furthermore, there has been an increasing recognition of the importance of strike-slip and partitioning of deformation within zones of crustal transpression (Dewey et al., 1998). Consequently, the possibility arises that the Southern Uplands sedimentary basin developed within an overall transpressional regime, with the main phase of the sinistral strike-slip deformation taking place during the Wenlock (Barnes et al., 1989; Barnes et al., 1995) associated with the final closure of the basin and docking of the Southern Uplands and Midland Valley terranes.

\section{Conclusions}

The Northern Belt of the Southern Uplands is dominated by turbiditic wacke sandstones, deposited in a sand-rich submarine fan environment, overlying hemipelagic mudstones of the Moffat Shale Group. Sandstones of the Tappins Group records the first input of sand-rich detritus, including juvenile ophiolitic material, into the Southern Uplands basin. The remainder of the Northern Belt sedimentary sequence is dominated by the relatively quartzose sandstones of the Kirkcolm and Shinnel formations, with the sediment having been derived from a Proterozoic continental source. This quartzose dominated sequence was punctuated by the input of fresh volcanic detritus (e.g. Galdenoch and Portpatrick formations) which was, at least in part, derived from an oceanic/continental island-arc source. Palaeocurrent data from comparable rocks in Ireland suggest that this volcanic source was situated to the W/NW of the Southern Uplands basin with sediment dispersal turning to the NE along the axis of the basin in Scotland. The continental/metamorphic source to the Southern Uplands sedimentary sequence is believed to be represented by the Midland Valley terrane of Scotland and Ireland (e.g. Tyrone Igneous Complex). This area was located to the NW of the Southern Uplands basin and may have provided arc-related volcanic, granitic plutonic, sedimentary and metasedimentary material to the Corsewall, Kirkcolm and Blackcraig formations. Published isotopic ages suggest that the volcanic detritus supplied to the Portpatrick Formation may have been derived much older mid-Cambrian to Arenig island-arc, possibly represented by the Tremadoc-Llanvirn volcanic rocks of the Curlew Mountains and/or South Mayo Trough. 
The tectonic setting of the Southern Upland basin remains uncertain as both the forearc/trench and back-arc basin models do not fully explain the geology of this complex terrane. The complex provenance of the sandstones and presence of major sedimentary breccia/olistostrome units within the Northern Belt suggest that it was tectonically active. This is in marked contrast to the preceding c. 20 Ma recorded by the Crawford Group in which there was a complete lack of terriginous clastic input into the Southern Uplands basin. The onset of clastic deposition within the Southern Uplands broadly corresponds to ophiolite obduction in both Scotland and Ireland, possibly in response to collision of a Cambrian-early Ordovician island-arc system (South Mayo Trough, Curlew Mountains, Co. Tyrone) with the Laurentian continental margin. If this interpretation is correct then the possibility arises that the Southern Uplands-Midland Valley terranes record the dismembering of this island-arc complex within an overall transpressional regime.

\section{Acknowledgements}

The paper has benefited from discussions with our colleagues in the Southern Uplands Regional Project, British Geological Survey. This paper is published with the permission of the Director, British Geological Survey (NERC).

\section{References}

Anderson, T. B. 1987. The onset and timing of Caledonian sinistral shear in County Down. Journal of the Geological Society of London. 144, 817-825.

Anderson, T. B. this volume.

Anderson, T. B. \& Oliver, G. J. H. 1986. The Orlock Bridge Fault: a major Late Caledonian sinistral fault in the Southern Uplands terrane, British Isles. Transactions of the Royal Society of Edinburgh: Earth Sciences. 77, 203-222.

Armstrong, H. A., Owen, A. W., Scrutton, C. T., Clarkson, E. N. K. \& Taylor, C. M. 1996. Evolution of the Northern Belt, Southern Uplands: implications for the Southern Uplands controversy. Journal of the Geological Society, London. 153, 197-205.

Armstrong, H. A. \& Coe, A. L. 1997. Deep-sea sediments record the geophysiology of the late Ordovician glaciation. Journal of the Geological Society of London. 153, 929-934.

Armstrong, H. A., Rushton, A. W. A., Owen, A. W., \& Floyd, J. D. 1998. Biostratigraphy of the Currarie Formation on the northwestern edge of the Southern Uplands: implications for the cessation of basic volcanism. Scottish Journal of Geology, 34, 119-125. 
Armstrong, H. A., A. W. A., Owen, A. W., \& Floyd, J. D. 1999. Rare earth geochemistry of the Arenig cherts from the Ballantrae Ophiolite and Leadhills Imbricate Zone, Southern Scotland: implications for origin and significance to the Caledonian Orogeny. Journal of the Geological Society, London, 156, 549-560.

Barnes, R. P., Lintern, B. C. \& Stone, P. 1989. Short Paper: Timing and regional implications of deformation in the Southern Uplands of Scotland. Journal of the Geological Society, London. 146, 905908.

Barnes, R. P., Phillips, E. R. \& Boland, M. P. 1995. The Orlock Bridge Fault in the Southern Uplands of southwestern Scotland: a terrane boundary ? Geological Magazine. 132, 523-529.

Barnes, R. P., Phillips, E. R. \& Merriman, R. J. 1996. Allocthonous Ordovician basaltic rocks of possible island arc affinity in the Southern Uplands, SW Scotland. Hibbard, J. P., van Staal, C. R. \& Cawood, P. A. (editors) New Perspectives in the Appalachian-Caledonian Orogen. Geological Association of Canada, Special Paper 41.

Bluck, B.J. 1983. Role of the Midland Valley of Scotland in the Caledonian orogeny Transactions of the Royal Society of Edinburgh: Earth Sciences. 74, 119-136.

Cameron, I. B., Stone, P. \& Smellie, J. L. 1986. Geology of the country around Girvan. Explanation of 1:50,000 British Geological Survey Sheet 7, Scotland.

Clarkson, E. N. K., Harper, D. A. T., Owen, A. W. \& Taylor, C. M. 1992. Ordovician faunas in massflow deposits, Southern Uplands. Terra Nova. 4, 245-253.

Clarkson, E. N.K., Harper, D.A.T., Owen, A. W. \& Taylor, C. M. 1993. Biggar, 180-191 in: McAdam, A. D., Clarkson, E. N. K. \& Stone, P. (eds) Scottish Borders Geology, an excursion guide. Edinburgh: Scottish Academic Press.

Craig, L. E. 1984. Stratigraphy in an accretionary prism: the Ordovician rocks in the North Down, Ireland. Transactions of the Royal Society of Edinburgh: Earth Sciences. 15, 183-191.

Daly, J. S. 1996. Pre-Carboniferous history of the Annagh Gneiss Complex, North-western Ireland, and correlation with Laurentia-Baltica. Irish Journal of Earth Sciences. 74, 5-18.

Danelian, T. \& Clarkson, E. N. K. 1998. Ordovician radiolaria from bedded cherts of the Southern Uplands. Scottish Journal of Geology. 34, 133-137. 
Danelian, T., Clarkson, E. N. K., Floyd, J. D. \& Armstrong, H. A. 1999. Radiolarian and conodont biostratigraphy of Arenig-Llanvirn chert sequences in the Southern Uplands of Scotland. British Geological Survey, Technical Report. WA/99/65.

Dempster, T. J. 1985. Uplift patterns and orogenic evolution in the Scottish Dalradian. Journal of the Geological Society, London, 142, 111-128.

Dewey, J. F., Holdsworth, R. E. \& Strachan, R. A. 1998. Transpression and transtension zones. In: Holdsworth, R. E., Strachan, R. A. \& Dewey, J. F. (eds) Continental Transpressional and Transtensional Tectonics. Geological Society, London. Special Publications 135, 1-14.

Duller, P. R. \& Floyd, J. D. 1995. Turbidite geochemistry and provenance studies in the Southern Uplands of Scotland. Geological Magazine. 132, 557-569.

Elders, C. F. 1987. The provenance of granite boulders in conglomerates of the Northern and Central Belts of the southern Uplands of Scotland. Journal of the Geological Society, London. 144, 853-863.

Evans, J. A., Stone, P. \& Floyd, J. D. 1991. Isotopic characteristics of Ordovician greywacke provenance in the Southern Uplands of Scotland. In: Morton, A. C., Todd, S. P. \& Haughton, P. D. W. (eds.). Developments in Sedimentary Provenance Studies. Geological Society of London, Special Publication. 57. 161-172.

Floyd, J. D. 1994. The derivation and definition of the 'Southern Upland Fault': a review of the Midland Valley-Southern Upland terrane boundary. Scottish Journal of Geology, 30, 51-62.

Floyd, J. D. 1996. Lithostratigraphy of the Ordovician rocks in the Southern Uplands: Crawford Group, Moffat Shale Group, Leadhills Supergroup. Transactions of the Royal Society of Edinburgh: Earth Sciences. 86, 153-165.

Floyd, J. D. 1999. Geology of the Carrick-Loch Doon district. Memoir of the British Geological Survey, 1:50,000 Geological Sheets 8W \& 8E (Scotland).

Floyd, J. D. \& Trench, A. 1989. Magnetic susceptibility contrasts in Ordovician greywackes of the southern Uplands of Scotland. Journal of the Geological Society, London. 146, 77-83.

Floyd, J. D. \& Rushton, A. W. A. 1993. Ashgill greywackes in the Southern Uplands of Scotland: an extension of the Ordovician succession in the Northern Belt. Transactions of the Royal Society of Edinburgh: Earth Sciences. 84, 79-85. 
Haughton, P.D.W. 1988. A cryptic Caledonian flysch terrane in Scotland. Journal of the Geological Society, London. 145, 685-703.

Hutchison, A. R. \& Oliver, G. J. H. 1998. Garnet provenance studies, juxtaposition of Laurentian marginal terranes and timing of the Grampian Orogeny in Scotland. Journal of the Geological Society, London. 155, 541-550.

Hutton, D. H. W., Aftalion, M. \& Halliday, A. N. 1985. An Ordovician ophiolite in County Tyrone, Ireland,. Nature, 315, 210-212.

Hutton, D. H. W. 1987. Strike-slip terranes and a model for the evolution of the British and Irish Caledonides. Geological Magazine, 124, 405-425.

Hutton, D. H. W. \& Dewey, J. F. 1986. Palaeozoic terrane accretion in the Western Irish Caledonides. Tectonics. 5, 1115-1124.

Kelley, S. \& Bluck, B. J. 1989. Detrital mica ages from the Southern Uplands using Ar-Ar laser probe. Journal of the Geological Society, London. 146, 401-403.

Kelley, S. \& Bluck, B. J. 1990. Discussion on detrital mica ages from the Southern Uplands using ArAr laser probe. Journal of the Geological Society, London. 147, 882-884.

Kelling, G., Davis, P. \& Holroyd, J. 1987. Style, scale and significance of sand bodies in the Northern and Central Belts, southwestern Southern Uplands. Journal of the Geological Society, London, 144, 787-805.

Lambert, R. St. J., Holland, J. G. \& Leggett, J. K. 1981. Petrology and tectonic setting of some Ordovician volcanic rocks from the Southern Uplands of Scotland. Journal of the Geological Society, London. 136, 755-770.

Lapworth, C. 1870. On the Lower Silurian Rocks in the neighbourhood of Galasheils. Transactions of the Geological Society of Edinburgh. 2, 46.

Lapworth, C. 1878. The Moffat Series. Quarterly Journal of the Geological Society of London. 43, 240346.

Leggett, J. K. 1980. The sedimentological evolution of a Lower Palaeozoic accretionary fore-arc in the Southern Uplands of Scotland. Sedimentology. 27, 401-17. 
Leggett, J. K. 1987. The Southern Uplands as an accretionary prism: the importance of analogues in reconstructing palaeogeography. Journal of the Geological Society, London, 144, 737-752.

Leggett J. K., McKerrow, W. S. \& Eales, M. H. 1979. The Southern Uplands of Scotland; a Lower Palaeozoic accretionary prism. Journal of the Geological Society, London, 136, 755-770.

Leggett, J. K., McKerrow, W. S. \& Casey, D. M. 1982. The anatomy of a Lower Palaeozoic accretionary fore-arc: the Southern Upland of Scotland. In Leggett, J.K. (ed.) Trench-fore-arc geology, Geological Society of London, Special Publication. 10.

Longman, C. D. Bluck, B. J., van Breeman, O. \& Aftalion, M. 1982. Ordovician conglomerates: constraints on the timescale. In Odin, G. S. (ed.). Numerical dating in stratigraphy. New York; Wiley, 807-9.

Meschede, M. 1986. A method of discriminating between different types of mid-ocean ridge basalts and continental tholeiites with the Nb-Zr-Y diagram. Chemical Geology. 56, 207-218.

McKerrow, W. S., Leggett, J. K. \& Eales, M. H. 1977. Imbricate thrust model of the Southern Uplands of Scotland. Nature. 267, 237-239.

McKerrow, W. S., Lambert, R. St. J. \& Cocks, L. R. M. 1985. The Ordovician, Silurian and Devonian periods. In: Snelling, N. J. (ed.). The Chronology of the Geological Record. Geological Society of London, Memoir No 10. 73-80.

Merriman, R. J. \& Roberts, B. 1990. Metabentonites in the Moffat Shale Group, Southern Uplands of Scotland: Geochemical evidence of ensialic marginal basin volcanism. Geological Magazine. 127, 259271.

Merriman, R. J. \& Kemp, S. J. 1998. Metamorphism of the Lower Palaeozoic rocks of the New Cumnock district, Southern Scotland, 1:50K Sheet 15W. British Geological Survey, Technical Report. WG/98/9.

Morris, J. H. 1987. The Northern Belt of the Longford-Down, Ireland and Southern Uplands, Scotland: an Ordovician back-arc basin. Journal of the Geological Society, London. 144, 773-786.

Nicol, J. 1848. On the geology of the Silurian rocks in the Valley of the Tweed. Quarterly Journal of the Geological Society, London. 4, 197. 
Owen, A. W. \& Clarkson, E. N. K. 1992. Trilobites from Kilbucho and Wallace’s Cast and the location of the Northern Belt of the Southern Uplands during the late Ordovician. Scottish Journal of Geology, 28, 317.

Owen, A. W., Armstrong, H. A. \& Floyd, J. D. 1999. Rare earth elements in chert clasts as provenance indicators in the Ordovician and Silurian of the Southern Uplands of Scotland. Sedimentary Geology. 124, 185-195.

Ogawa, Y. 1998. Tectonostratigraphy of the Glen App area, Southern Uplands, Scotland: anatomy of an Ordovician accretionary prism. Journal of the Geological Society, London. 155, 651-662.

Peach, B. N. \& Horne, J. 1899. The Silurian rocks of Britain. Volume 1. Scotland. Memoirs of the Geological Survey of the United Kingdom.

Pearce, J. A. 1983. Role of the sub-continental lithosphere in magma genesis at active continental margins. In Continental basalts and mantle xenoliths (ed. C. J. Hawkesworth \& M. J. Norry). Shiva Publishing Ltd: Nantwich, Cheshire. 230-249.

Pearce, J. A. \& Cann, J. R. 1973. Tectonic setting of basic volcanic rocks determined using trace element analyses. Earth and Planetary Science Letters. 19, 290-300.

Phillips, E. R., Barnes, R. P., Merriman, R. J. \& Floyd, J. D. 1995. The tectonic significance of Ordovician basaltic rocks in the Southern Uplands, SW Scotland. Geological Magazine. 132. 549-556.

Phillips, E. R., Barnes, R. P., Boland, M. P., Fortey, N. J. \& McMillan, A. A. 1995. The Moniaive Shear Zone: A major zone of sinistral strike-slip deformation in the Southern Uplands of Scotland. Scottish Journal of Geology. 31. 139-149.

Phillips, E. R. Smith, R. A. \& Carroll, S. 1998. Strike-slip, terrane accretion and the pre-Carboniferous evolution of the Midland Valley of Scotland. Transactions of the Royal Society Edinburgh: Earth Sciences. 89. pp 209-224.

Phillips, E. R. Smith, R. A. \& Floyd, J. D. 1999. The Bail Hill Volcanic Group: alkaline within-plate volcanism during Ordovician sedimentation in the Southern Uplands, Scotland. Transactions of the Royal Society Edinburgh: Earth Sciences. 89, 233-247.

Phillips, E. R. \& Floyd, J. D. 1999. The mineralogy, petrology and provenance of lithic clasts from Ordovician and Silurian conglomerates from the Southern Uplands of Scotland. British Geological Survey, Technical Report, WG/99/5. 
Rock, N. M. S., Gasgarth, J. W. \& Rundle, C. C. 1986. Late Caledonian dyke-swarms in Southern Scotland: a regional zone of primitive K-rich lamprophyres and associated vents. Journal of Geology. 94, 505-22.

Rushton, A. W. A. 1995. Graptolites from the area north of Sanquhar. British Geological Survey, Technical Report. WH/95/203R.

Rushton, A. W. A. \& Stone, P. 1991. Terriginous input to the Moffat Shale sequence, Southern Uplands. Scottish Journal of Geology. 27, 167-169.

Scrutton, C. T., Jeram, A. J. \& Armstrong, H. A. 1998. Kilbuchophyllid corals from the Ordovician (Caradoc) of Pomeroy, C. Tyrone: implications for coral phylogeny and for movement on the Southern Uplands Fault. Transactions of the Royal Society of Edinburgh: Earth Sciences. 88, 117-126.

Smith, R. A. 1999. Geology of the New Cumnock district. Description of 1:50 000 geological sheet 15W (Scotland) .BGS: Keyworth and Edinburgh

Stone, P., Floyd, J. D., Barnes, R. P. \& Lintern, B. C. 1987. A sequential back-arc and foreland basin thrust duplex model for the Southern Uplands of Scotland. Journal of the Geological Society, London. 144, 753-764.

Stone, P., Green, P. M., Lintern, B. C., Plant, J. A., Simpson, P. R. \& Breward, N. 1991. Geochemistry characterises provenance in southern Scotland. Geology Today. 7, 177-180.

Stone, P. \& Evans, J. A. 1995. Nd-study of provenance patterns across the Iapetus Suture. Geological Magazine. 132, 571-580.

Styles, M. T. Stone, P. \& Floyd, J. D. 1989. Short Paper: arc detritus in the Southern Uplands; mineralogical characterisation of a 'missing' terrane. Journal of the Geological Society, London. 146, $397-$ 400 .

Styles, M. T., Perez-Alverez, M. \& Floyd, J. D. 1995. Pyroxenous greywackes in the Southern Uplands of Scotland and their petrotectonic implications. Geological Magazine. 132, 539-547.

Taira, A., Okada, H., Whitaker, J. H. McD. \& Smith, A. J. 1982. The Shimanto Belt of Japan: CretaceousLower Miocene active-margin sedimentation. In: Leggett, J. K (ed.). Trench-Forearc Geology. Geological Society of London, Special Publication No 10. 5-26. 
Thirlwall, M. F. 1981. Peralkaline rhyolites from the Ordovician Tweeddale lavas, Peebleshire, Scotland. Geological Journal. 16, 41-44.

Walker, R. G.1978. Deep Water Sandstone Facies and Ancient Submarine Fans: Models for Exploration for Stratigraphic Traps. The American Association of Petroleum Geologists Bulletin, 62, 932-966.

\section{Figures}

Fig. 1. Outline geological map of the Northern Belt of the Southern Uplands showing the main tracts and their component formations. Inset shows a tectono-biostratigraphical diagram constructed across the centre of the Northern Belt. SUF - Southern Upland Fault; CF - Carcow Fault; GF - Glaik Fault; LIZ - Leadhills Imbricate Zone; FF - Fardingmullach Fault; OBF - Orlock Bridge Fault.

Fig. 2. Geological map of the New Cumnock-Leadhills area, showing the main structures, rudites and volcanic rocks.

Fig. 3. Diagrams for discriminating between basaltic rocks from different tectonic settings: (a) $\mathrm{Zr} / \mathrm{Y}-\mathrm{Zr}$ (Pearce \& Cann 1973); (b) Nb*2 - Zr/4 - Y (Meschede 1986); (c) MORB normalised (Pearce 1983) multielement spider diagram. Data from other Ordovician basaltic volcanic rocks within the Southern Uplands (Lambert et al., 1981; Phillips et al., 1995; Barnes et al., 1996; BGS unpublished data) and the Tweeddale lavas (Thirlwall 1981) are also shown.

Fig. 4. Comparative sections through the Tappins Group showing the overall coarsening upwards of the Corsewall Formation, and contrasting fining upward sequence recorded by the Marchburn Formation.

Fig. 5. Depositional models for the Marchburn, Corsewall, Kirkcolm, Portpatrick and Shinnel formations of the Northern Belt.

Fig. 6. A comparison of composite sections in the Barrhill, Bail Hill Volcanic and Scaur groups, together with the Shinnel Formation, highlighting the presence of rudaceous, basic clast-rich and volcanic rocks. BHV - Bail Hill Volcanic Group; BLKC - Blackcraig Formation; GDF - Galdenoch Formation; GWH - Glenwhargen Formation; KKF (N) \& KKF (S) - northern and southern Kirkcolm Formation; POLT - Poltallan Member; SHIN - Shinnel Formation; SPOT - Spothfore Member; STOD - Stoodfold Member.

Fig. 7. A diagrammatic vertical section of the Northern Belt in the New Cumnock area showing the main structures and tract-bounding faults together with the component groups and formations. BHV - 
Bail Hill Volcanic Group; GDF - Galdenoch Formation; GWH - Glenwhargen Formation; KKF Kirkcolm Formation; MCHB - Marchburn Formation; TAP - Tappins Group.

Fig. 8. Schematic palaeo-reconstruction (gracilis-linearis Biozones) showing the relative positions of the Southern Uplands terrane and the Midland Valley terrane of Co. Tyrone, Ireland based upon the removal of an estimated 200-250 km of post late-Silurian sinistral displacement along the Southern Upland and related faults. C - Curlew Mountains; SMT - South Mayo Trough; T - Tyrone Complex. See Fig. 1 for lithostratigraphic codes. 